Article

\title{
Covid-19 and the Environment: Challenges and Opportunities
}

\author{
Nima Norouzi*, Zahra Bashashjafariabadi \\ Department of energy engineering and physics, Amirkabir university of technology (Tehran polytechnic), 424 \\ Hafez Avenue, PO Box 15875-4413, Tehran, Iran \\ *Correspondence: nima1376@aut.ac.ir
}

How to cite this paper: Norouzi, N., \& Bashashjafarabadi, Z. (2021).

Covid-19 and the Environment: Challenges and Opportunities. Research Journal of Ecology and Environmental Sciences, 1(1), 39-51. Retrieved from https://www.scipublications.com/journal/index.php/rjees/article/view/64

Received: July 2, 2021

Accepted: August 8, 2021

Published: August 9, 2021

Copyright: (c) 2021 by the authors. Submitted for possible open access publication under the terms and conditions of the Creative Commons Attribution (CC BY) license (http://creativecommons.org/licenses /by/4.0/).

\begin{abstract}
After the outbreak of the covid-19 disease in the world of human life, living organisms and their environment were affected in various ways. The outbreak of the covid-19 virus has posed many opportunities and challenges to the world environment. This article aims to investigate the effects of the outbreak of covid-19 disease on the environment. This research has studied the effects of the covid-19 virus on the environment through library and review methods. It has been studied and analyzed in the form of articles and related researches. The results of published sources show that quarantine and the requirement of humans to stay at home to break the covid-19 transmission chain caused the animals to feel safe, move out of their natural territory and into urban and rural areas. Reducing noise and air pollution and greenhouse gas emissions by reducing vehicle traffic and shutting down factories are other positive effects of the covid-19 outbreak that has helped improve air quality and reduce global warming. In addition to these positive effects, reducing conservation activities during the Covid-19 era in some areas has increased habitat destruction and poaching. Increasing household and hospital waste production, increasing the consumption of plastics and disposable materials, and decreasing waste recycling are the negative effects of the covid-19 virus epidemic, which, by destroying resources, puts pressure on the environment. Increased consumption of detergents and disinfectants will have many detrimental effects on the environment. In general, the positive effects of the covid-19 virus on the temporary and short-term environment seem to be small compared to the long-term consequences. Therefore, by overcoming covid-19, we should focus on rebuilding society and a healthy economy, and by fully understanding the opportunities and threats of this virus, we should consciously train environmental behaviors.
\end{abstract}

Keywords: Biodiversity; Environment; Climate change; covid-19; Pandemic.

\section{Introduction}

The environment is a set of living and non-living factors that interact with each other. Human life on earth is intertwined with the physical and biological environment around it and its resources. Due to the increasing population of the world, the relationship between humans and the environment has taken on wide forms and dimensions, followed by numerous environmental problems such as pollution, climate change, and habitat destruction. The type of human use of land has a great impact on the life of different plant and animal species. When the balance of the environment is artificially disturbed by humans, latent viruses can be easily transmitted from animals to humans.

Researchers believe that due to the extinction of natural habitats, different species are forced to be close to each other, and as a result, pathogens are transmitted from one species to another. Hunting animals as a portion of food and selling food in world markets causes viruses to jump from animals to humans [2]. Viruses such as HIV, Ebola, dengue fever, and the covid-19 virus have infected humans due to large-scale disturbance of cognitive balance.

Covid-19 viruses are a large family of viruses introduced in the 1960s and can infect animals and humans. Many strains of the covid-19 virus have been identified so far, some 
of which are transmitted to humans [3]. The covid-19 virus causes a wide range of respiratory infections in humans, ranging from the common cold to more severe illnesses such as the Middle East respiratory syndrome and acute respiratory syndrome. The latter, called the covid-19 virus, also causes cold-like symptoms and shortness of breath.

The virus was identified in late 2019 in Wuhan in China and spread throughout the world with the spread of the disease in humans [4].

Fatigue and dry cough are the most common symptoms of Covid disease. Some patients may have other symptoms, such as pain and bruising, nasal congestion, runny nose, sore throat, or gastrointestinal problems (such as diarrhea). The virus infects the respiratory system and can lead to death [5]. This virus has a long evolutionary relationship and correlation with bats, but it is unclear that this virus was transmitted directly from bats to humans or through mediators [6]. A survey of the first people infected with the virus showed that most of these people had returned to the market selling live animals. It is likely that the virus has been transmitted from animals to humans and has almost spread to the rest of the world, causing millions of people to develop Kuwait disease [4].

After the outbreak of the covid-19 disease in human life, living organisms and the environment were affected in various ways. Quarantine laws and the requirement to stay at home were enforced in many countries, leading to the first evacuation of freeway highways, the downing of airplanes, and declining global oil demand. The less human activity, the fewer resources are consumed and the less destructive its effects on the living and non-living factors of the environment. Thus, the spread of the covid-19 virus has posed many opportunities and challenges to the world environment. This article examines the effects and consequences of the outbreak of covid-19 disease on the environment, which has been studied and analyzed based on scientific articles, reports, and related research.

\section{Methods and Materials}

This research has analyzed, summarized, and reflected the results of related findings with a promotional approach to shed light on the effects and consequences of the outbreak of covid-19 disease on the environment. This research is one of the types of analytical research done using the review method and library.

\section{Results and Discussion}

After the outbreak of the Covid-19 disease, an examination of published sources showed that human life, living organisms, and the environment had been affected in various ways, with many opportunities and challenges. The prevalence of Covid-19 disease and its impact on the environment can be divided into its positive and negative consequences (Figure 1), which are discussed below. 


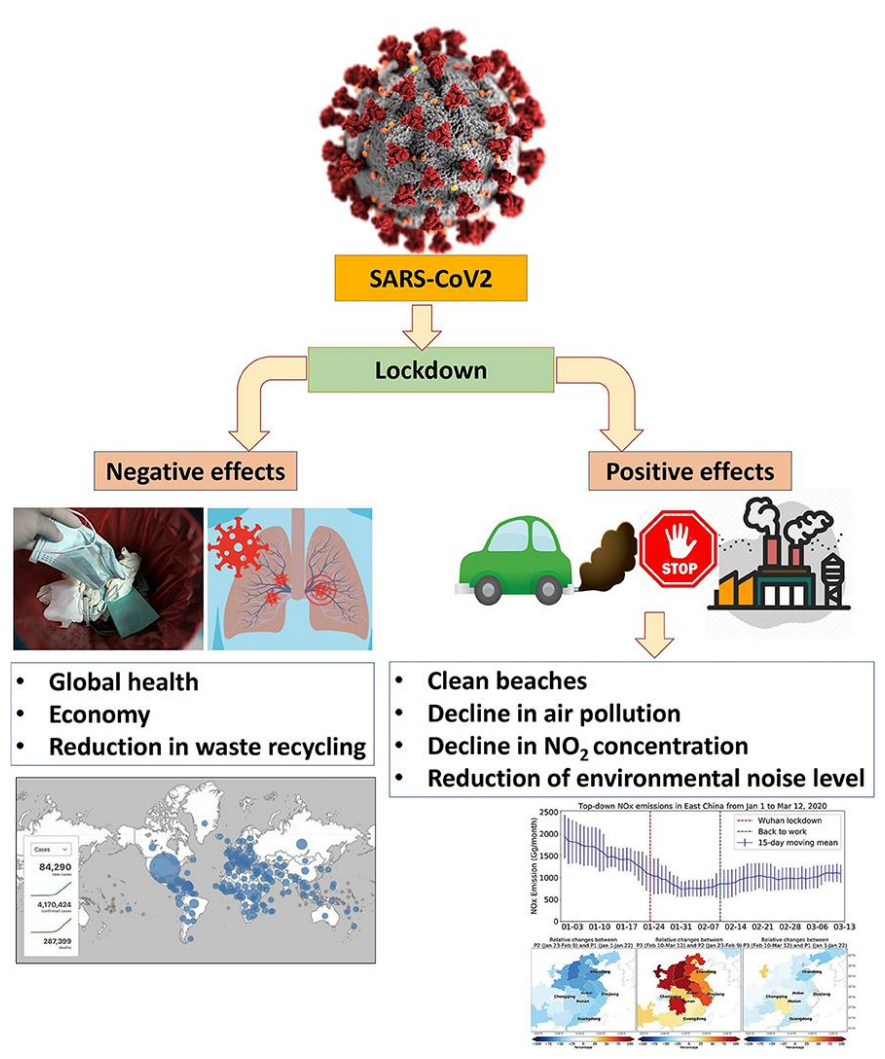

Figure 1. Positive and negative effects of the covid-19 virus on the environment [7].

\subsection{Positive effects of the covid-19 virus on the environment}

\subsection{1. effect of covid-19 on biodiversity}

The type of human use of land has a great impact on various plant and animal species. Destruction and conversion of natural habitats to other uses have narrowed the field for different species and isolated species [7]. Animals have no choice but to take refuge in remote areas at a time when humans have infiltrated almost all of their areas of life and are shrinking their natural range. The outbreak of the covid-19 epidemic in different parts of the world has left people at home to break the covid-19 transmission chain. Quarantine and the obligation to keep humans at home caused the animals to leave their natural territory and come to urban areas. People in different countries have published pictures of wild animals on the streets of the city. For example, in various cities in India, species such as leopards, elephants, deer, and peacocks have been reported in the streets and public places [8]. The presence of coyotes on the streets of California and deer and wild boar have been observed in various cities in France and Spain [8,9]. The arrival of animals in urban areas reminds us that many of our cities have been the habitat of these animals, destroyed and occupied by humans. For example, the destruction of agricultural lands and the destruction of panda habitats in China have made this very rare species found today only in a few mountains in central China [10]. The panda is a very sensitive species and is difficult to reproduce in captivity, and its reproduction in captivity is done only through artificial insemination. Following the outbreak of the covid-19 virus and the spread of wildlife and amusement parks to the public, officials at the Hong Kong Conservation and Recreation Center have announced that a pair of pandas have become pregnant after ten years. The inhuman world seems to have been useful to the world's wildlife, albeit temporarily.

One of the covid-19 epidemic and home quarantine characteristics is that it coincides with the wildlife breeding season. The number of wildlife road accidents is increasing every year due to the many trips from late to late April. Although there are no accurate statistics on the number of wildlife casualties, the reduction in travel and movement of 
people due to the limitations of the epidemic has been effective in reducing the number of accidents [12]. In addition, with the ban on hunting licenses throughout Iran by the Environmental Protection Agency, hunting of wildlife is expected to decrease significantly [13]. This is due to the reduction of traffic on the one hand and the fear of the virus spreading from animal to human. Many poachers travel by vehicle and are not native to the areas where they hunt. With prolonged covid-19 epidemics, poaching may increase due to constraints and economic pressures on local communities [12]. We saw similar conditions a few years ago with the outbreak of bird flu. When the hunting ban was announced, hunters, for fear of contracting the disease, laid down their weapons and did not hunt. For this reason, we saw migratory birds in the country's wetlands that year because these animals felt safe. In the following years, when hunting began again, many of these migratory birds were not observed in the wetlands [14].

The effect of covid-19 outbreak conditions on wildlife species is not the same [15]. Species that are dependent on human beings for feeding on human beings in public places and will starve. The animals that live in its orchards have also become accustomed to and dependent on humans and human attention. These animals also have problems with humans and daily visits. The closure of many catering establishments and restaurants is causing food shortages for species such as foxes, which typically move out of protected areas for food due to easy access to food and along the roadsides and residential and service units. [9]. Changes in food behavior are consequences of habitat destruction by humans, and species with special nutritional, habitat, and needs are more harmed [15].

\subsubsection{Reduce air pollution and greenhouse gas emissions}

Citizens not leaving their homes and not using cars have reduced air pollution in large and industrial cities. Air pollution has disappeared in cities with very limited horizons for years, and natural features can be seen for miles. In China, for example, which experienced the largest quarantine period in its history, and in January 2020, the number of people traveling decreased. Following the application of traffic restrictions, the air pollution index showed a significant decrease, and pollutant gases from fumes such as sulfur dioxide and nitrogen dioxide decreased [16]. Air quality is one of the important elements for public health. According to the World Health Organization, more than $90 \%$ of the world's population lives in areas that are not in good condition in air quality [17]. Today, the effects and consequences of air pollution are not hidden from anyone, and the increase of air pollutants brings with it diseases and deaths. According to the World Health Organization, $8 \%$ of the world's deaths are due to the consequences of pollution [17]. Due to traffic restrictions in Europe, the European Union Air Pollution Monitoring Service has reported the production of particulate matter by 20 to $30 \%$ and a reduction in sulfur dioxide and nitrogen dioxide emissions. [18]. Climate change on earth has reduced the endangered species' habitats and is threatening them [19]. The lives of many survivors Preliminary studies show that carbon monoxide, which is mostly produced by cars, has dropped by about 50 percent compared to 2019. On the other hand, carbon dioxide production, which contributes to climate change through global warming, has also decreased in recent days [15]. For example, the European Space Agency, using the Sentinel-5 satellite, has shown that the level of air pollution, especially over Italy, has decreased by about a quarter or more of carbon dioxide emissions in that country. Also, the average level of nitrogen dioxide, which is closely related to the consumption of fossil fuels, in the week after the Chinese New Year, this year was 36\% lower than the same period last year (Figure 2). 

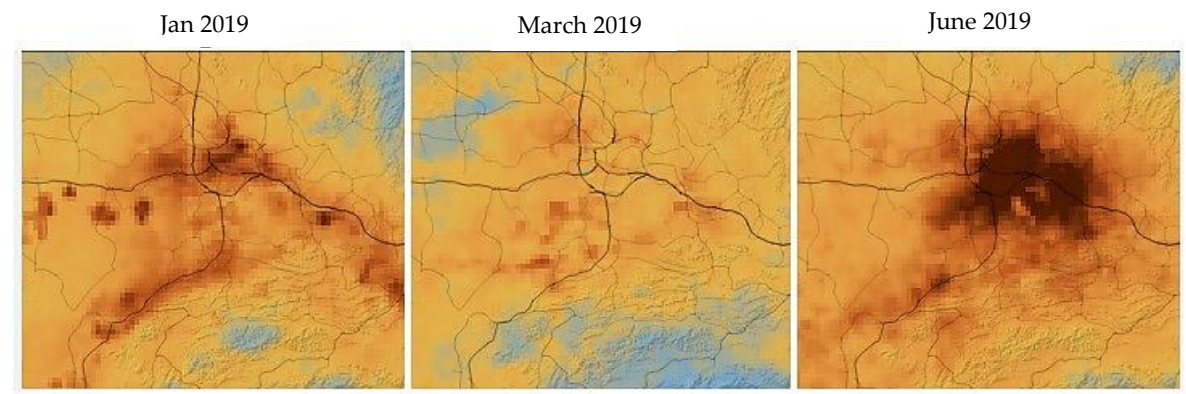

Jan 2020

March 2020

June 2020

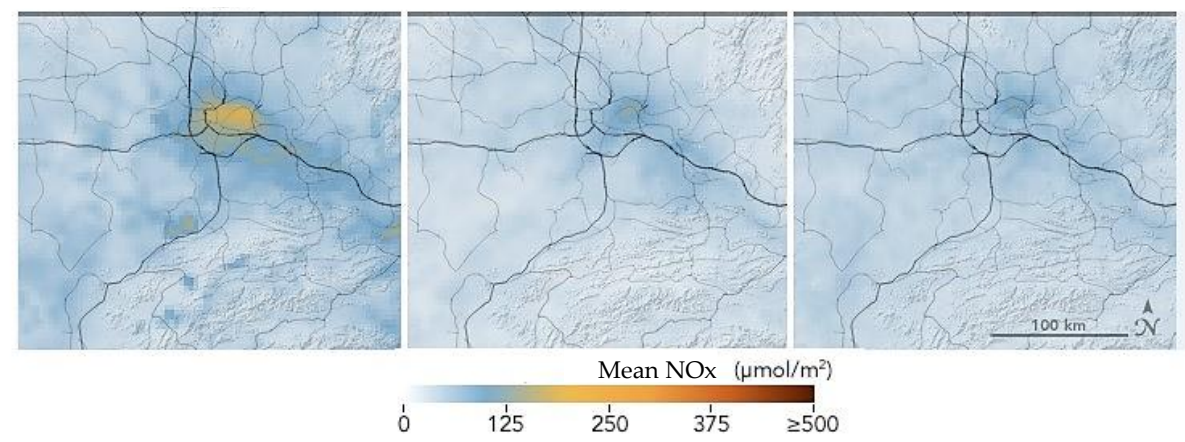

Figure 2. Changes in the emission and concentration of pollutant gases such as nitrogen dioxide in China between January and March 2019 and 2020 [21].

\subsection{3. cleanliness of beaches and seas}

Two-thirds of the earth's surface is covered with water, the habitat of many living things, and a place for human relaxation and recreation. Maritime / coastal tourism is one of the types of tourism that related activities take place in both coastal and aquatic environments. Tourism has played an important role in the economy of local communities and is effective in sustainable development. The development of the tourism industry in recent decades has caused these areas to be damaged and destroyed with large numbers of tourists [22]. Pollution is one of the threatening factors of aquatic ecosystems. Hypoplastic bottles and various wastes do not detract from the beauty of this environment and pose many dangers to animals that live in the sea. Eight million tons of plastic waste enter the oceans every year [23]. The cessation of tourism activities is one of the consequences of the covid-19 epidemic in the world. The lack of tourists in coastal areas has led to a reduction in pollution caused by them, such as reducing garbage and waste.

The tourism industry has suffered greatly since the outbreak of the covid-19 virus, but the cessation of coastal and maritime activities has had a major impact on the appearance and cleanliness of beaches in different parts of the world. For example, the coasts of Spain and Mexico, which are considered to be among the most polluted beaches in the world due to the abundance of tourists and all kinds of beach and sea recreation, spent the clearest and cleanest times during the Covid-19 era.

\subsubsection{Noise pollution}

Noise from motor vehicle and industry traffic and car traffic are considered annoying factors in cities that cause mental stress, behavioral problems, and illnesses necessary to avoid home [24]. Noise generation sources have been significantly reduced. According to the recorded results of the stations of the air quality control company, by applying traffic restrictions from March, telecommuting of employees, and closure of commercial centers, the average sound level in the time of day will decrease by an average of about 1 to $2 \mathrm{~dB}$ to 2018 and 2019 (Figure 2). 


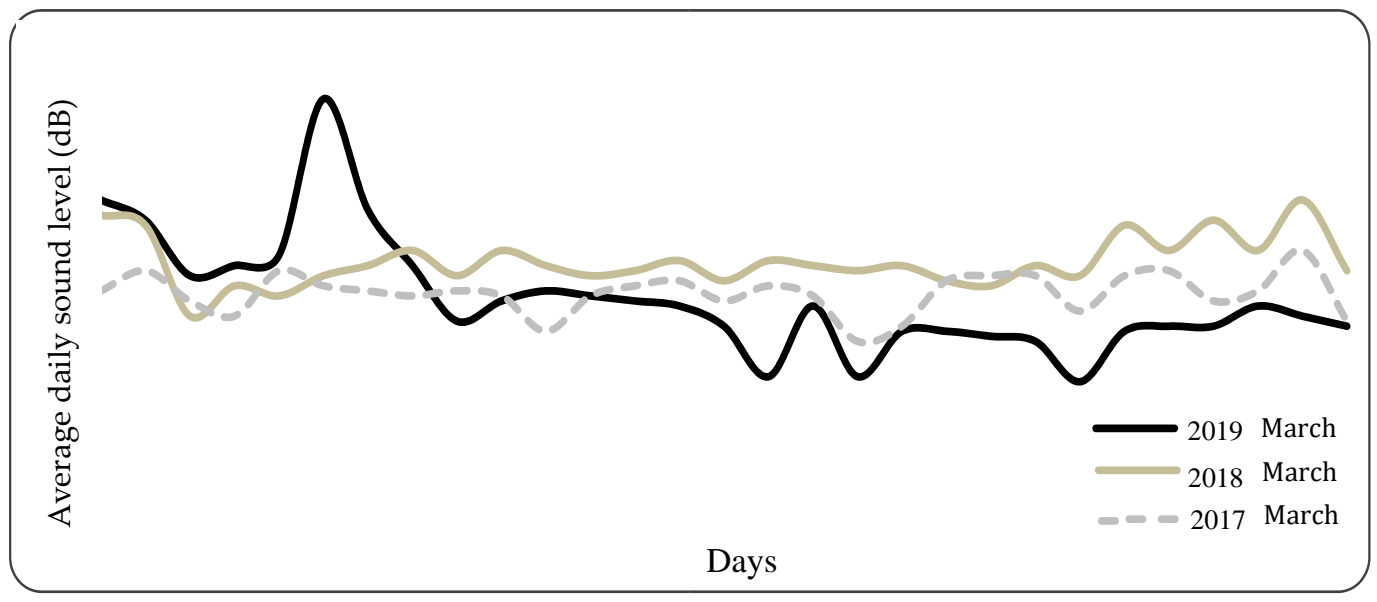

Figure 3. Average daily sound level in fixed sound measuring stations in Tehran [21].

\subsection{Negative effects of Covid-19 virus on the environment}

\subsubsection{Increase in poaching}

In many African countries, a large portion of the biodiversity conservation budget comes from nature tourism activities. These activities have declined sharply with the prevalence of Covid-19, and in many cases, tourism activities have stopped. In Namibia, for example, the tourism industry provides employment and a source of income for about 20 percent of the country's population. The cessation of tourism activities following the outbreak of the Covid-19 virus has led to the loss of a source of income for this segment of the population, which has several consequences. In Tanzania, about a quarter of the country is protected, and as the Crona epidemic continues in the world and tourists are drastically reduced, many people will lose their incomes, and conservation budgets will be drastically reduced [15]. Conservation forces in these areas will decrease, and poaching will increase. These people, who lose their income, go hunting for their livelihood and that of their families. Species such as rhinos and elephants that have valuable horns are hunted and endangered. This phenomenon reduces the population of wildlife species and wastes the conservation activities spent on these species and their population growth. The uncontrolled perception of human beings from the world's natural resources has always threatened the environment and wildlife. Undoubtedly, the capital that has existed on earth for centuries does not belong only to the present generation in the world and must be preserved for future generations.

As an example of the quarantine and homelessness of the people of the world, the efforts of poachers to kill a rare unicorn rhino in India have increased. Quarantine laws and traffic restrictions in India have caused animals to move out of national parks and protected areas, move on highways and get closer to cities. This has made them more vulnerable to poachers. Poachers sell each rhino horn on the black market for about $\$ 150,000$. Some of them even receive $\$ 60,000$ per kilogram of the animal's horn. The demand for rhino horn as an active ingredient in traditional Chinese medicine is very high. Indian officials had reported that illegal rhinoceros hunting had increased since late March when global quarantine began in India [25].

\subsubsection{Increased deforestation}

The outbreak of Covid-19 disease has severely affected the economy and severely damaged many jobs. This increased the destruction of natural areas and wood smuggling. So much so that in the days of the Covid-19 virus outbreak, the destruction of natural resources in some parts of the world was as rapid as the outbreak of the virus. In Iran, with the outbreak of the Covid-19 virus and its coincidence with the Nowruz holiday, the 
situation created for business people and economic conditions destroyed forests to accelerate [12]. The closure of businesses in urban communities led to the return of many people from the city to the villages where they were born. Rising wood prices, wood chips, coal production, and increased demand have led to more abuse of natural resources. The idea that natural resources are free in public opinion has led to an increase in deforestation in many areas, including the Zagros forests [26]. With the destruction of forest areas, due to the special climatic conditions of these areas and restrictions such as reduced humidity and lack of regeneration, there is no possibility of revitalizing these forests.

The Amazon rainforest, which is the largest rainforest globally, is also witnessing a similar degradation process. Based on satellite images provided by the European Space Research Institute, deforestation in the Amazon has intensified during the Covid-19 outbreak [27].

Timber smugglers are taking advantage of this situation, reducing government oversight, and cutting down trees extensively because limited government resources are being spent on controlling Covid-19 disease and reducing the possibility of adequate oversight in the Amazon rainforest. The Brazilian Space Agency reports that from January 2020 to April of that year, at the same time as the outbreak of the Covid-19 virus, approximately 1,200 square kilometers of these forests were destroyed so that these forests could be considered indirect victims of the Covid-19 virus (Figure 4).

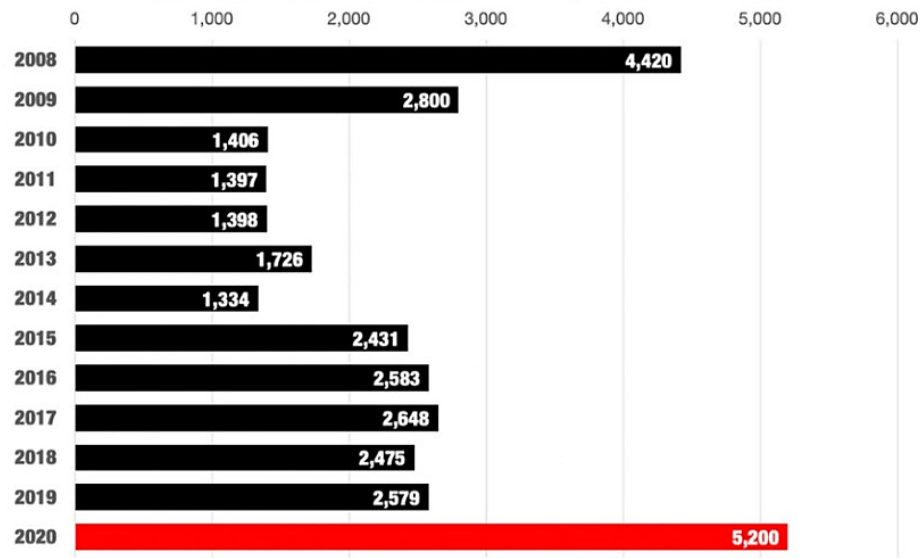

Figure 4. Deforestation statistics in the Amazon region from August to March of each year (20082020) in terms of square kilometers.

\subsubsection{Prevalence of Covid-19 and the problem of abandoning animals in nature}

It seems that the Covid-19 virus was transmitted from animal to human in the second edition [6]. There was a direct transmission of the Kuwait 19 virus from bats to humans or through intermediate animals such as snakes and ants [1,2]. The virus can be transmitted from an infected person or another person and transmitted to animals. Scientists were quick to investigate how the virus behaved in animals. Preliminary studies by scientists have shown that the Covid-19 virus can also be transmitted to animals and infect them, but the bodies of these organisms are more resistant to viruses and less likely to die than the physiological structure of the human body [28]. The first sick animal to test positive for the Kuwait 19 virus was a respiratory tiger at the New York Zoo [29]. After that, a few milk and tiger cubs in the zoo showed signs of Kuwait 19 disease. Researchers believe that these large cats became ill after being exposed to a zoo guard, infected with the virus. In addition, there is a possibility of transmitting the disease from humans to animals, especially pets, and the result of the Covid 19 test was positive in some domestic dogs and cats in Hong Kong, Belgium, and the United States [30]. Concerns about Covid-19 disease have led to the release of pets, especially cats, into the wild [31]. The Animal Health Organization called on people worldwide not to harass animals due to the spread of the Covid-19 
virus and not to leave their pets. These animals, like humans, are victims and should be respected. It should not be forgotten that pets also need support and care during this crisis. Pets are dependent on humans, and because they have not learned the skills of living outside the home, they can not adapt to the environment. Most pets can not find food and water and defend themselves against other animals. Therefore, these animals can not survive outside the house and die.

UNESCO adopted the Universal Declaration of Animal Rights in 1987, stating that all animals have equal rights to life. Any animal dependent on humans should be properly cared for and cared for, and animals that depend on humans should not be unfairly abandoned or killed [33]. Therefore, abandoning animals in practice is unethical and can have many health risks to the environment and negatively affect biodiversity. Pets are not considered part of wildlife or a collection of natural creatures. Leaving animals such as dogs and cats in the wild causes damage to the habitat and creates stress in the native wildlife of the region [34]. For example, creating stress changes the behavior of birds and their unwanted migration. Abandoned animals, if they survive, compete with other animals for food, shelter, and nesting, and while mating with species close to them, destroy the genetic purity of wild species. Released animals in nature are considered a threat to the safety and health of the people. For example, the feces of these animals can be the basis for transmitting various diseases to humans [35].

\subsubsection{Expansion of invasive species}

When a species enters a habitat outside its natural habitat, it is called a non-native species. In many cases, non-native species can become invasive. Due to their high adaptability, migratory species are more successful in competing with native species and grow and reproduce rapidly in their new habitat. As a result, they reduce the population of native species and lead the endemic species to extinction. In addition to the great damage they do to the ecosystem, invasive species can cause economic damage (including damage to agricultural land and water pipes). Experts believe that the spread of invasive species and the threat of endemic species is one of the consequences of the outbreak of the Covid19 virus [36]. Stopping or reducing human conservation activities to eliminate non-native and invasive species from invasive species. With the reduction of conservation and management programs, the number of invasive species increases and threatens the survival of their population by competing with native species.

\subsubsection{Water and wetland pollution}

With the outbreak of the Covid-19 virus and the increase in handwashing sensitivities, water consumption has increased significantly worldwide [37]. After the outbreak of Covid-19 and according to the report of the Office of Water Utilization Supervision, water consumption has increased in large cities such as Tehran (26\%), Isfahan (25\%), Shiraz $(22 \%)$, and Tabriz (23\%) [38]. This issue is especially important in areas of the country that have naturally always faced water shortages. Iran is a country with an arid and semi-arid climate and has always faced natural disasters such as drought. Increased use of detergents and disinfectants is another negative effect of the Covid-19 crisis on the environment [39]. The outbreak of Covid-19 disease has led to an increase in global demand for disinfectants, detergents, and other health items. For example, the purchase of disinfectants, detergents, and other hygiene products in the United States (Figure 5) has shown a significant increase in [40]. Increasing this detergent and disinfectant increases water and wetland pollution and adversely affects living organisms [39]. 


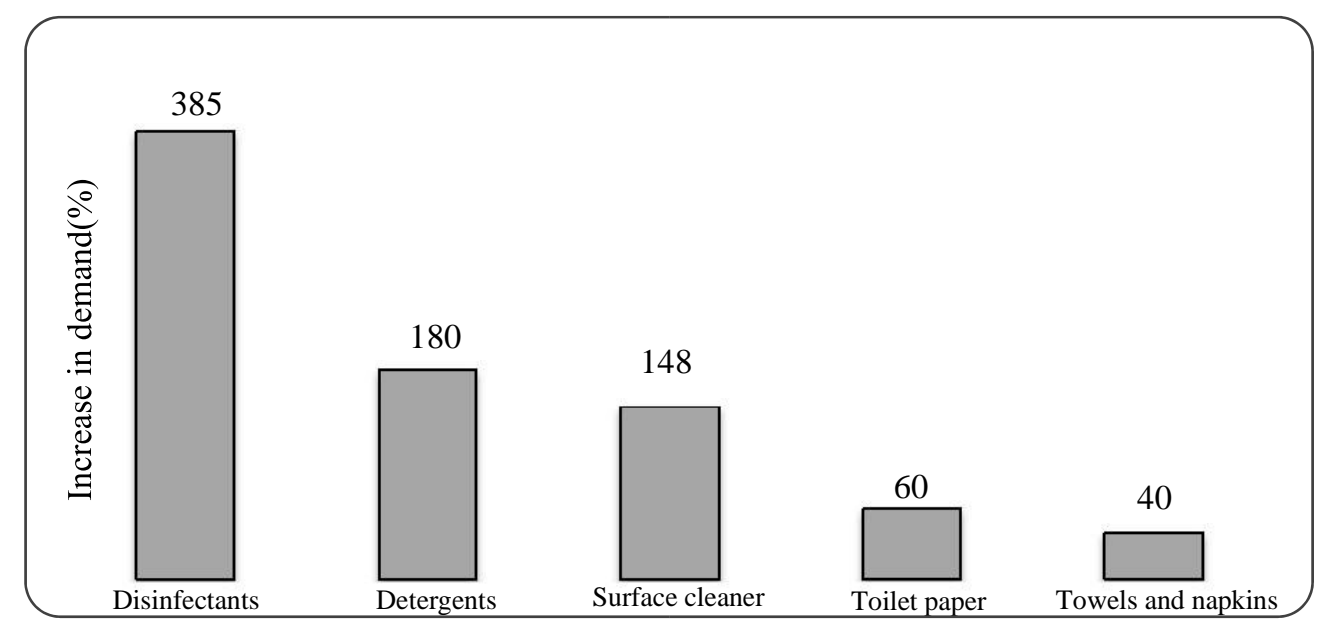

Figure 5. Rising purchases of disinfectants, detergents, and health items in the United States following the outbreak of Covid-19 in March 2020 [40].

\subsubsection{Increase waste, decrease recycling and waste separation}

The amount and composition of hospital and even municipal and household waste has changed with the Covid-19 crisis. Consumption of individuals and families increased dramatically following the spread of Covid-19 worldwide. The increase in online shopping increased the amount of waste in cities. Due to the contamination of wastes such as masks, gloves, guns, shoes, etc., with the virus, the disposal of these wastes in safe and virus-free conditions is very important [41]. The sudden increase in waste generation, which is mostly hospital waste, in addition to concerns about the pathogenicity of waste, has posed a major challenge to the environment [42]. It is believed that the segregation of wastes causes the virus to spread further, and therefore all of them should be disposed of in the same way that they are collected. Some developed countries have prepared instructions and asked people to divide their waste into three categories; Distinguish between wet, dry and non-recyclable [43]. Covid-19 infectious waste is also recycled in non-recyclable waste to be disposed of in special incinerators. In China, for example, $97 \%$ of household waste is incinerated [42].

Restrictions on the segregation and recycling of municipal waste in many countries worldwide have been one of the most influential factors on the environment since the outbreak of Kuwait. For example, in Tehran, 7,500 tons of waste is generated daily, which, following the outbreak of the Covid-19, all the waste in Tehran is buried, and no waste is separated [44]. Garbage, hospitals, plastics, paper, and glass have all been dumped into large potholes. Landfilling all waste will be a great disaster because, besides wasting returnable capital, they contaminate soil and water, and a large amount of land is spent on landfilling. Garbage is referred to as dirty gold. By burying garbage, in addition, to easily losing this valuable substance, we turn our land into a swamp of garbage. At the same time, this waste can be recycled and put into the production cycle. Waste that is not recyclable should also be reduced to compact materials that take up the least space. Waste heats up when it is in the recycling stage. This means that if they are also infected with the Covid-19 virus, they will be cleansed of the infection in this process. This process alone can eliminate the Covid19 virus and prevent the loss of large capital [44]. Forces operating at the demarcation lines become unemployed during the Covid-19 outbreak. The closure of waste separation stations will be to the detriment of these workers. Its social and environmental aspects are also diminishing. 


\subsubsection{Increase consumption of plastics and disposable supplies}

Another new problem and consequence of the Covid-19 crisis that needs to be managed are disposable gloves, masks, and their release into the environment and public spaces. Disposable plastics and materials do not decompose in the environment and will have long-term consequences for the environment[45]. In recent years, methods to reduce plastic materials have been implemented in many countries, but at present, due to greater caution and fear of an increase in the Covid-19, strict measures to reduce plastic pollution are not being implemented in the past[46]. Concerns about the safety and contamination of the virus have led to the lifting of the ban on the use of disposable plastics, and as a result, the demand for water bottles, plastic bags, and plastic packaging has increased. Since the onset of covid disease, many stores have banned their reusable bags and replaced them with disposable plastic bags [47, 48].

Duration of this virus on different surfaces Studies have shown that the durability of this virus on plastic is longer than materials such as paper and cardboard [49]. However, plastic bags with a high risk of transmission are also used, and the priority of using cardboard and paper bags with a lower risk of transmission of this disease is ignored. In Iran, from the first days of the onset of the Covid-19 disease, the Environmental Protection Agency has issued instructions to municipalities to install pedal bins in public places so that citizens do not come into contact with the least amount of garbage. But some people do not pay attention to this issue. Not much attention has been paid to the contamination caused by plastic protective devices against the virus. The use of protective products such as masks, gloves, and other plastic medical devices and their release into the environment cause these substances to enter the water and block the waterways[50].

\section{Conclusions}

After the eruption and the eruption of molten material, the land around the volcano becomes very fertile, and farmers in these areas plant a variety of plants and seeds and nutritious harvest crops. This threatening situation is similar to the current state of the world in the face of the Covid-19 virus. Covid-19 can be considered a fire that has descended on humans and, despite overwhelming hardships, paints hope for a better future for all living things. The Covid-19 pandemic, from a human point of view, can be just an opportunity or a threat to health. Do not make life difficult for all kinds of animals with their interventions; let them continue their lives in peace. Of course, it is not yet possible to accurately assess the future effects of Covid-19 on the environment, and the passage of time will shed light on many issues. If the invasion and persistence of the virus are prolonged, it will have a profound effect on human life and the environment.

The temporary reduction in fossil fuel consumption, which has led to a reduction in air pollution and greenhouse gases, has brought joy to many environmentalists. Wild animals gained more freedom, and the beaches were cleared of garbage. This has led some to view the Covid-19 virus as a savior of nature. This is even though reducing greenhouse gas emissions in the face of the huge amount of pollution humans have introduced into the environment after the Industrial Revolution is not a long time. The release and temporary return of animals to nature are insignificant in the face of the destruction of wildlife habitats and their uncontrolled hunting. The positive effects of the Covid-19 virus on the environment seem to be temporary, like painkillers.

Moreover, such conditions have not been based on human consciousness and choice. In other words, the prevalence of Covid-19 has not changed human attitudes toward nature, and behavior toward nature has not improved. In contrast, the outbreak of the Covid-19 virus increases the production of high volumes of waste, increases the consumption of plastic and disposable goods, increases the production of waste, increases the con- 
sumption of water, reduces the consumption of water and energy, and pollutants. Another important point is achieving sustainable development, and one must pay attention to the economy and the environment.

Covid-19 dealt a heavy blow to the world economy and spread poverty. Under such circumstances, governments will move towards meeting the basic needs of society, will not be strict on industries, and as a result, the environment will be sacrificed. The covid19 virus has caused many social and economic problems, and in the current situation, attention to the environment will not be a priority. At the same time, the environment, along with society and the economy, is an important three sides to achieving sustainable development. In a world where the Covid-19 virus is killing people in society and destroying the economy, the discourse of the environment will not be heeded.

In general, the positive effects of the Covid-19 virus on the temporary and short-term environment seem to be small compared to the long-term outcomes. The inhumane world is good for the world's wildlife, but it has many facets, and the effects of the Covid-19 virus on the environment will only become clear over time. The positive effects of Covid19 on the pre-hurricane environment appear to be positive, and the virus should not be viewed as a savior of nature. Therefore, it is necessary to focus on overcoming Covid-19, rebuilding a healthy society and economy, and consciously educating environmental behaviors by fully understanding the opportunities and threats of the virus.

Supplementary Materials: The paper is not supported by additional material.

Author Contributions: “Conceptualization, NN, and NN; methodology, NN; software, ZB; validation, $\mathrm{ZB}, \mathrm{ZB}$, and $\mathrm{ZB}$; formal analysis, $\mathrm{NN}$; investigation, $\mathrm{NN}$; resources, $\mathrm{NN}$; data curation, $\mathrm{NN}$; writing - original draft preparation, NN; writing-review and editing, NN; visualization, $\mathrm{ZB}$; supervision, $\mathrm{ZB}$; project administration, $\mathrm{ZB}$; funding acquisition, $\mathrm{ZB}$ All authors have read and agreed to the published version of the manuscript."

Funding: "This research received no external funding."

Data Availability Statement: The data will be available by an official request from the corresponding author.

Acknowledgments: Authors, as a result of this, thank the scientific supports of Amirkabir university of technology.

Conflicts of Interest: "The authors declare no conflict of interest."

\section{References}

[1] Xu, Z.; Shi, L.; Wang, Y.; Zhang, J.; Huang, L.; Zhang, C.; Liu, S.; Zhao, P.; Liu, H.; Zhu, L.; et al. Pathological findings of COVID-19 associated with acute respiratory distress syndrome. Lancet Respir. Med. 2020, 8, 420-422.

[2] Sohrabi, C.; Alsafi, Z.; O’Neill, N.; Khan, M.; Kerwan, A.; Al-Jabir, A.; Iosifidis, C.; Agha, R. World Health Organization declares global emergency: A review of the 2019 novel coronavirus (COVID-19). Int. J. Surg. 2020, 76, 71-76.

[3] Spinazzè, A.; Cattaneo, A.; Cavallo, D.M. COVID-19 Outbreak in Italy: Protecting Worker Health and the Response of the Italian Industrial Hygienists Association. Ann. Work Expo. Health 2020, 64, 559-564.

[4] Zambrano-Monserrate, M.A.; Ruano, M.A.; Sanchez-Alcalde, L. Indirect effects of COVID-19 on the environment. Sci. Total Environ. 2020, 728, 138813.

[5] Saadat, S.; Rawtani, D.; Hussain, C.M. Environmental perspective of COVID-19. Sci. Total Environ. 2020, 728, 138870.

[6] Gautam, S.; Hens, L. COVID-19: Impact by and on the environment, health and economy. Environ. Dev. Sustain. 2020, 22, 4953-4954.

[7] Venter, Z.S.; Aunan, K.; Chowdhury, S.; Lelieveld, J. COVID-19 lockdowns cause global air pollution declines with implications for public health risk. medRxiv 2020, 7162.

[8] Sharma, S.; Zhang, M.; Gao, J.; Zhang, H.; Kota, S.H. Effect of restricted emissions during COVID-19 on air quality in India. Sci. Total Environ. 2020, 728, 138878.

[9] Kumar, A.; Malla, M.A.; Dubey, A. With Corona Outbreak: Nature Started Hitting the Reset Button Globally. Front. Public Health, 2020, 8, 569353. doi: 10.3389/fpubh.2020.569353.

[10] Collivignarelli, M.C.; Abbà, A.; Bertanza, G.; Pedrazzani, R.; Ricciardi, P.; Carnevale Miino, M. Lockdown for CoViD-2019 in Milan: What are the effects on air quality? Sci. Total Environ. 2020, 732, 139280. 
[11] Bar, H. COVID-19 lockdown: Animal life, ecosystem and atmospheric environment. Environ. Dev. Sustain. 2020, 1-18.

[12] Sarkar, M.; Das, A.; Mukhopadhyay, S. Assessing the immediate impact of COVID-19 lockdown on the air quality of Kolkata and Howrah, West Bengal, India. Environ. Dev. Sustain. 2020, 1-30.

[13] Yunus, A.P.; Masago, Y.; Hijioka, Y. COVID-19 and surface water quality: Improved lake water quality during the lockdown. Sci. Total Environ. 2020, 731, 139012.

[14] Rowan, N.J.; Laffey, J.G. Challenges and solutions for addressing critical shortage of supply chain for personal and protective equipment (PPE) arising from Coronavirus disease (COVID19) pandemic-Case study from the Republic of Ireland. Sci. Total Environ. 2020, 725, 138532.

[15] Park, C.-Y.; Kim, K.; Roth, S.; Beck, S.; Kang, J.W.; Tayag, MC; Grifin, M.; Asian Development Bank; World Health Organization. Global Shortage of Personal Protective Equipment amid COVID-19: Supply Chains, Bottlenecks, and Policy Implications. ADB Briefs 2020, 108, 1-8.

[16] Klemeš, J.J.; Van Fan, Y.; Tan, R.R.; Jiang, P. Minimising the present and future plastic waste, energy and environmental footprints related to COVID-19. Renew. Sustain. Energy Rev. 2020, 127, 109883.

[17] Yu, H.; Sun, X.; Solvang, WD; Zhao, X. Reverse logistics network design for effective management of medical waste in epidemic outbreaks: Insights from the coronavirus disease 2019 (COVID-19) outbreak in Wuhan (China). Int. J. Environ. Res. Public Health 2020, 17, 1770.

[18] Patrício Silva, A.L.; Prata, J.C.; Walker, T.R.; Duarte, A.C.; Ouyang, W.; Barcelò, D.; Rocha-Santos, T. Increased plastic pollution due to COVID-19 pandemic: Challenges and recommendations. Chem. Eng. J. 2021, 405, 126683.

[19] Prata, J.C.; Silva, A.L.P.; Walker, T.R.; Duarte, A.C.; Rocha-Santos, T. COVID-19 Pandemic Repercussions on the Use and Management of Plastics. Environ. Sci. Technol. 2020, 54, 7760-7765.

[20] Adyel, T.M. Accumulation of plastic waste during COVID-19. Science 2020, 369, 1314-1315.

[21] Fadare, O.O.; Okoffo, E.D. Covid-19 face masks: A potential source of microplastic fibers in the environment. Sci. Total Environ. 2020, 737, 140279.

[22] Lambert, S.; Sinclair, C.J.; Bradley, E.L.; Boxall, ABA Environmental fate of processed natural rubber latex. Environ. Sci. Process. Impacts 2013, 15, 1359-1368.

[23] Briassoulis, D.; Aristopoulou, A.; Bonora, M.; Verlodt, I. Degradation Characterisation of Agricultural Low-density Polyeth-ylene Films. Biosyst. Eng. 2004, 88, 131-143.

[24] Sen, SK; Raut, S. Microbial degradation of low density polyethylene (LDPE): A review. J. Environ. Chem. Eng. 2015, 3, 462473.

[25] Bellasi, A.; Binda, G.; Pozzi, A.; Galafassi, S.; Volta, P.; Bettinetti, R. Microplastic Contamination in Freshwater Environments: A Review, Focusing on Interactions with Sediments and Benthic Organisms. Environments 2020, 7, 30.

[26] Consiglio dei Ministri Decreto del Presidente del Consiglio dei Ministri 26 Aprile 2020. Available online: http://www.governo.it/sites/new.governo.it/files/Dpcm_img_20200426.pdf (accessed on 28 April 2020).

[27] Kumar, H.; Azad, A.; Gupta, A.; Sharma, J.; Bherwani, H.; Labhsetwar, N.K.; Kumar, R. COVID-19 Creating another problem? Sustainable solution for PPE disposal through LCA approach. Environ. Dev. Sustain. 2020, 1-15.

[28] Remuzzi, A.; Remuzzi, G. COVID-19 and Italy: What next? Lancet 2020, 395, 1225-1228.

[29] Paterlini, M. On the front lines of coronavirus: The Italian response to covid-19. BMJ 2020, 368, m1065.

[30] Grasselli, G.; Zangrillo, A.; Zanella, A.; Antonelli, M.; Cabrini, L.; Castelli, A.; Cereda, D.; Coluccello, A.; Foti, G.; Fumagalli, R.; et al. Baseline Characteristics and Outcomes of 1591 Patients Infected With SARS-CoV-2 Admitted to ICUs of the Lombardy Region, Italy. JAMA 2020, 323, 1574.

[31] Spina, S.; Marrazzo, F.; Migliari, M.; Stucchi, R.; Sforza, A.; Fumagalli, R. The response of Milan's Emergency Medical System to the COVID-19 outbreak in Italy. Lancet 2020, 395, e49-e50.

[32] Armocida, B.; Formenti, B.; Ussai, S.; Palestra, F.; Missoni, E. The Italian health system and the COVID-19 challenge. Lancet Public Health 2020, 5, e253.

[33] ISTAT Istituto Nazionale di Statistica. Available online: https://www.istat.it/ (accessed on 30 April 2020).

[34] Lab24 Coronavirus. Available online: https://lab24.ilsole24ore.com/coronavirus/ (accessed on 15 January 2021).

[35] Huang, Z.; Huang, J.; Gu, Q.; Du, P.; Liang, H.; Dong, Q. Optimal temperature zone for the dispersal of COVID-19. Sci. Total Environ. 2020, 736, 139487.

[36] ISS Indicazioni ad Interim per la Gestione dei Rifiuti Urbani in Relazione Alla Trasmissione Dell'infezione da Virus SARSCOV-2. Available online: https://www.iss.it/altre-pubblicazioni/-/asset_publisher/btw1J82wtYzH/content/id/5299930 (accessed on 12 May 2020).

[37] Ministero del Lavoro e Delle Politiche Sociali Protocollo Condiviso di Regolamentazione Delle Misure per il Contrasto e il Con-tenimento Della Diffusione del Virus Covid-19 Negli Ambienti di Lavoro. Available online: https://www.lavoro.gov.it/notizie/Documents/Protocollo-24-aprile-2020-condiviso-misure-di-contrasto\%20Covid-19.pdf (accessed on 2 May 2020).

[38] Regione Lombardia Portale Istituzionale. Available online: https://www.regione.lombardia.it/wps/portal/istituzionale/ (accessed on 3 May 2020).

[39] Unioncamere Lombardia Camere di Commercio Lombarde. Available online: http://www.unioncamerelombardia.it/?/home (accessed on 6 May 2020). 
[40] Coldiretti Coldiretti. Available online: https://www.coldiretti.it/ (accessed on 4 May 2020).

[41] Confcommercio Ristorazione-Rapporto Annuale. 2019. Available online: https://www.confcommercio.it/documents/20126/0/Rapporto+Ristorazione+2019+Fipe.pdf/27de185c-4d5d-9e60-abc4-7248d254846e?version=1.0\&t=1579623545575 (accessed on 16 May 2020).

[42] ISFORT Rapporto Sulla Mobilità Degli Italiani “Audimob". Available online: https://www.isfort.it/progetti/17-rapportoaudimob-sulla-mobilita-degli-italiani/ (accessed on 15 May 2020).

[43] AGI Coronavirus e Lockdown, il Pesante Conto per le Imprese. Available online: https://www.agi.it/economia/news/202006-15/coronavirus-imprese-lockdown-istat-8903854/ (accessed on 9 December 2020).

[44] ISS Raccomandazioni ad Interim sui Disinfettanti Nell'attuale Emergenza COVID-19: Presidi Medico Chirurgici e Biocidi. Available online: https://www.epicentro.iss.it/coronavirus/pdf/rapporto-covid-19-19-2020.pdf (accessed on 30 April 2020).

[45] Van Fan, Y.; Jiang, P.; Hemzal, M.; Klemeš, J.J. An update of COVID-19 influence on waste management. Sci. Total Environ. 2021, 754, 142014.

[46] Norouzi, N.; Zarazua de Rubens, G.; Choubanpishehzafar, S.; Enevoldsen, P. When pandemics impact economies and climate change: Exploring the impacts of COVID-19 on oil and electricity demand in China. Energy Research and Social Science 2020, 68.

[47] Norouzi, N. Post-COVID-19 and globalization of oil and natural gas trade: Challenges, opportunities, lessons, regulations, and strategies. Int J Energy Res. 2021, 1- 19. https://doi.org/10.1002/er.6762

[48] Norouzi, N.; Zarazua de Rubens, G.Z.; Enevoldsen, P.; Behzadi Forough, A. The impact of COVID-19 on the electricity sector in Spain: An econometric approach based on prices. Int J Energy Res. 2021, 45, 6320- 6332. https://doi.org/10.1002/er.6259.

[49] Norouzi, N.; Ataei, E. Covid-19 Crisis and Environmental Law: Opportunities and Challenges. Hasanuddin Law Review. 2021, 7(1), 46-60.

[50] Norouzi, N.; Khanmohammadi, H.; Ataei, E. The Law in the Face of the COVID-19 Pandemic: Early Lessons from Uruguay. Hasanuddin Law Review, 2021, 7(2), 75-88. doi:http://dx.doi.org/10.20956/halrev.v7i2.2827. 